\title{
Types of corrosion damage of tubing in the oilfield
}

\author{
Natalya Devyaterikova*,1, Marianna Nurmukhametova ${ }^{1}$, Aleksandr Kharlashin ${ }^{2}$, Yegor Popov ${ }^{2}$ \\ ${ }^{1}$ JSC Pervouralsk New Pipe Plant, Pervouralsk, Russian Federation \\ ${ }^{2}$ Ural State University named after the First President of Russia B.N.Yeltsin, Yekaterinburg, Russian Federation
}

\begin{abstract}
The accumulated research data of tubing fragments after operation made it possible to generalize and systematize information on the prevailing type of corrosion damage and operating conditions that determine the mechanism of their development. Understanding basic laws of the development of corrosion processes in specific operating conditions, allows to select the optimal type of tubing for these conditions more accurately.
\end{abstract}

\section{Introduction}

During the development of the Material Selection System for specific conditions of oil production, at JSC "PNTZ" studies were conducted for the tubing operating conditions, and evaluation of their impact on the nature of corrosion damages was done. The accumulated research data of more than 100 tubing fragments made it possible to generalize and systematize information on the prevailing type of corrosion damage and operating conditions that determine the mechanism of their development. The understanding of the mechanism of corrosion damage allows to specify requirements for tubing with increased operational reliability. In this article, we review the influence of specific factors of operation on the course of corrosion processes.

\section{Process}

For more than 10 years, PNTZ JSC has used and developed the system for selecting tubing materials for oil production, including:

- methods of evaluation of corrosion processes of production equipment in oil and gas wells;

- the pipe selection system depending on the operating corrosion factors;

- several new tubing ranges of series $\mathrm{Cr} 1, \mathrm{Cr} 3$ and $\mathrm{Cr} 5$ of the corresponding corrosion resistance group $(\mathrm{S}, \mathrm{C}, \mathrm{CS}$, SS) [1].

During the development of the Material Selection System for specific conditions of oil production, at JSC "PNTZ" together with a number of research centers researches were conducted for the tubing operating conditions, and evaluation of their impact on the nature of corrosion damages was done.

Depending on the prevalence of certain corrosion factors, the following main types of corrosion in the oil and gas industry can be distinguished $[2,3,4]$ :

- carbon dioxide corrosion;

\footnotetext{
* Corresponding author: Natalya.Devyaterikova@chelpipe.ru
}

- hydrogen sulphide corrosion;

- fretting corrosion;

- stress corrosion cracking;

- microbial corrosion.

The regularities of the corrosion process in a complex system, which is formed during oil production, are determined by many factors, the main ones of which are the content of carbon dioxide and hydrogen sulphide (both primary and secondary which is bacterial). The mineral composition of accompanying waters, temperature and pressure conditions in the well, salt formation processes, etc. can be considered as complicating factors $[1,2,3,4]$.

The examination of the pipe fragments after operation in different conditions allows to obtain a lot of information on the prevailing mechanisms of corrosion and the influence of various factors on the process. At the same time the understanding of the mechanism of corrosion damage allows to specify requirements for tubing with increased operational reliability.

As a rule, the following works shall be necessarily performed within such researches:

- data collection on operating conditions and analysis of documentation provided by the oil company;

- fractographic investigations;

- analysis of corrosion products;

- determination of chemical composition and mechanical properties of the material;

- metallographic examination of the material, including examination at the point of defects occurrence;

- bacteriological studies.

\section{Examples of different types of corrosion damage}

There are many examples of different types of corrosion damage caused by the above factors.

Thus, under the influence of low-aggressive corrosive environments with a small number of factors contributing to the localization of corrosion processes (chlorides, 
carbon dioxide, erosion wear, etc.) in the formation of a loose non-protective film of corrosion products that does not prevent the corrosive environment from accessing the metal surface, a general uniform corrosion develops (fig. $1)$.

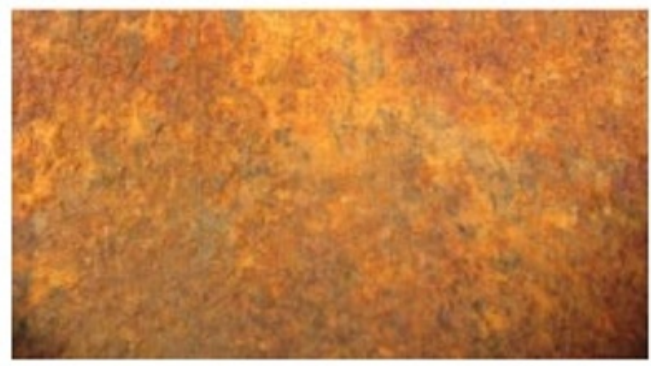

Fig. 1. General uniform corrosion (OOO Stavropolneftegaz, Zimnyaya Stavka Field, 112 days)

This type of corrosion in most cases is found at the initial stage of corrosion, regardless of the content of aggressive gases and their ratio. During long-term operation, uniform corrosion was observed in primarily hydrogen sulfide-containing corrosive environment along with SSC (with a low $\mathrm{CO}_{2}$ content).

The vast majority of cases of corrosion damage in oilfield environments can be attributed to the manifestations of general uneven corrosion. Local corrosion can be considered as a special case of this type of corrosion: pitting, ulcer corrosion and mesa corrosion.

Pitting corrosion is characterized by the formation of defects in the form of deep point damages, usually in environments with a high concentration of chloride ions, as well as after hydrochloric acid treatments. Often, in the process of further operation there is a merger of pitting and the rapid development of ulcer corrosion (fig. 2).

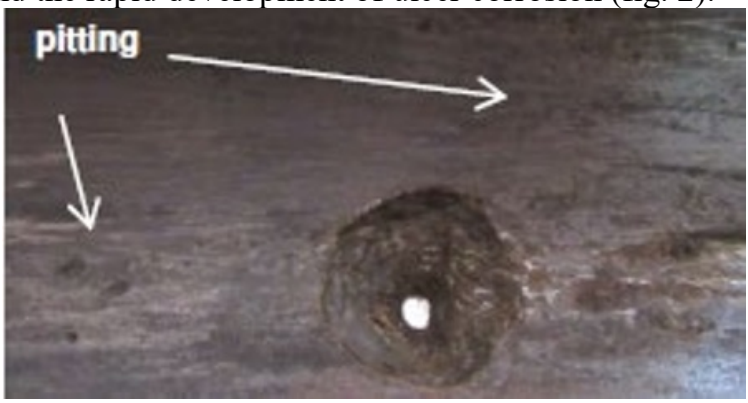

Fig. 2. Pitting corrosion (OOO Bashneft-Dobycha, Arlanneft Field Office, 70 days)

Ulcer corrosion in the form of a "classical" spherical ulcer, starting at one point on the surface of the metal, goes further with approximately the same speed both deep into the metal and on the surface (fig. 3).

The slopes of ulcers are well expressed; the area of the bottom is much smaller than the area of the mouth of the ulcer. It occurs in almost all aggressive environments of Russian oil companies with different content and ratio of $\mathrm{CO}_{2}$ and $\mathrm{H}_{2} \mathrm{~S}$ (almost $50 \%$ of all cases of corrosion damage). There have been single cases of the formation of classic ulcers in the environment with a primary H2Scorrosion (speed to $25 \mathrm{~mm} /$ year).

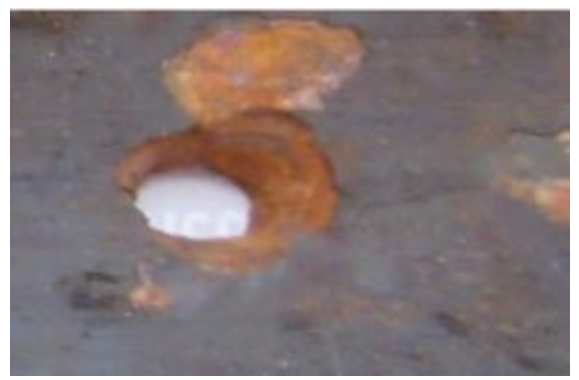

Fig. 3. Through ulcer corrosion (OOO LUKOIL-Zapadnaya Sibir, TPP Povneftegaz, Vatieganskoye field, 172 days)

Mesa corrosion is a kind of ulcer corrosion which is featured by significant areas of local corrosion damage of irregular shape, which are interspersed with areas of metal, not affected by corrosion at all (fig. 4). It is observed in about $25 \%$ of cases of corrosion damage, sometimes along with ulcer corrosion, mainly at increased $\mathrm{CO}_{2}$ content $\left(\mathrm{pCO}_{2}\right.$ more than $\left.0.5 \mathrm{~atm}\right)$. Among the complicating factors, high velocities of the gas-liquid flow, mechanical admixtures, the presence of significant amounts of chlorides are usually observed, i.e. factors contributing to the periodic destruction of protective films of corrosion products and localization of corrosion damage.

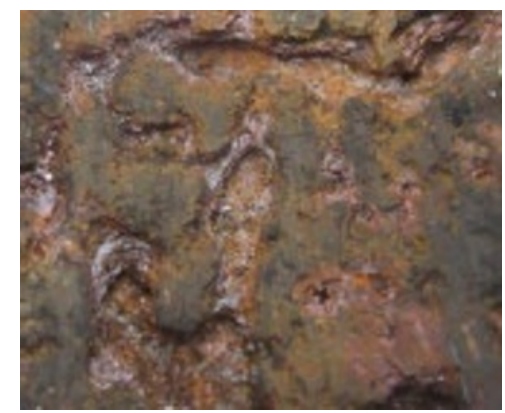

Fig. 4. Mesa corrosion to through corrosion (OAO Tomskneft, Talovoye field, 329 days)

A kind of this type of corrosion can be considered corrosion damage in form subsurface ulcers, characterized by the formation of defects with vertical walls or with walls with a negative angle of inclination with a flat bottom (fig.5). In this case, the side walls of the damage can be significantly affected by corrosion. There are about $5-10 \%$ of cases of corrosion damage. This type of damage is observed with a predominant $\mathrm{CO}_{2}$ content of more than $0.6 \mathrm{~atm}$, while hydrogen sulphide is not detected at all or there is its presence in small quantities. This type of corrosion develops at a high rate Among the complicating factors, high temperatures $\left(97-110^{\circ} \mathrm{C}\right)$, the presence of a dense layer of sediments

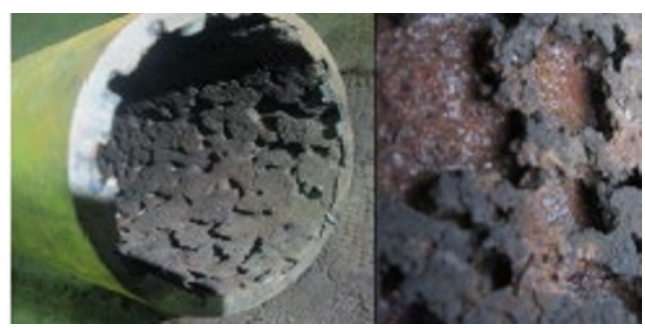


Fig. 5. Mesa corrosion in form subsurface ulcers (OOO Gazpromneft-Vostok, South-Western part of Krapivinskoye field, 39 days)

on the surface of areas not affected by corrosion, the presence of significant amounts of chlorides are normally observed. In some cases acid treatments are evidenced.

The mechanism of development of such damage requires understanding; as a preliminary version one can consider the development of corrosion damage under a layer of tight corrosion products starting at the places of local damage of deposits or pitting.

Analysis of the effect of temperature and carbon dioxide content on the nature of corrosion ulcer shows that the temperature and partial pressure of $\mathrm{CO}_{2}$ increase in a number of Ulcer-corrosion - Mesa-corrosion - Mesacorrosion with high rate (Fig.6)

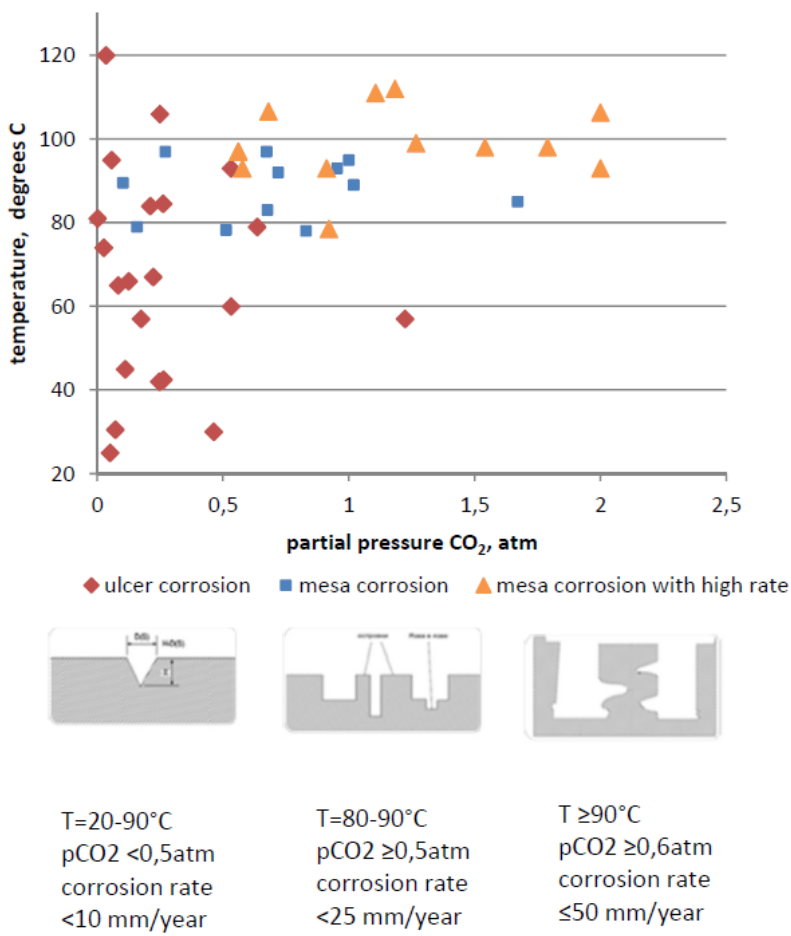

Fig. 6 Types of ulcer corrosion depending on the temperature and $\mathrm{CO}_{2}$ content in the well

One of the causes of local corrosion is bacterial corrosion. During long-term operation, ulcers of a regular shape, which are formed by the adhered colonies of bacteria, merge, deepen and form through ulcers with well-defined slopes in a form of a spherical ulcer (fig. 7).

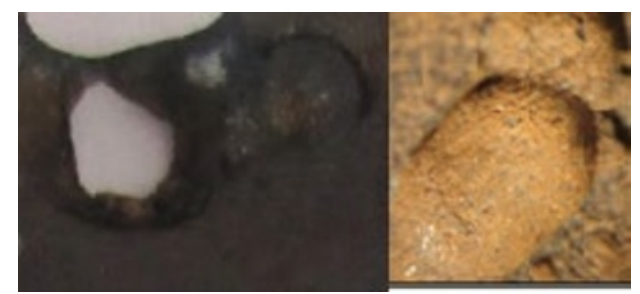

Fig. 7. Bacterial corrosion (OOO Lukoil-KOMI, Varandeyskoye field, 316 days).

According to our observations, the probability of localization and the rate of development of all types of local corrosion increase with an increasing $\mathrm{CO} 2$ concentration.

One of the common examples of damage is corrosion mechanical wear. A classic example is the wear of the inner surface of the pipe by the pump rods when using sucker rod pumps (fig. 8). The formation of wear in wells with ESP raises questions (fig. 9). Perhaps this is due to cleaning from asphaltene-resin-paraffin deposits by scraping.

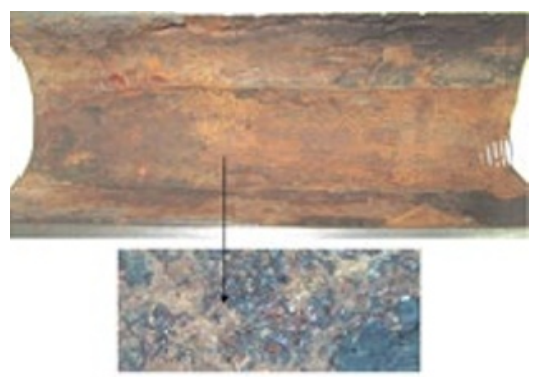

Fig. 8. Corrosion-mechanical wear of the inner surface of the pipe pump rods (OOO LUKOIL-Perm, Batyrbaiskoye field, 187 days).
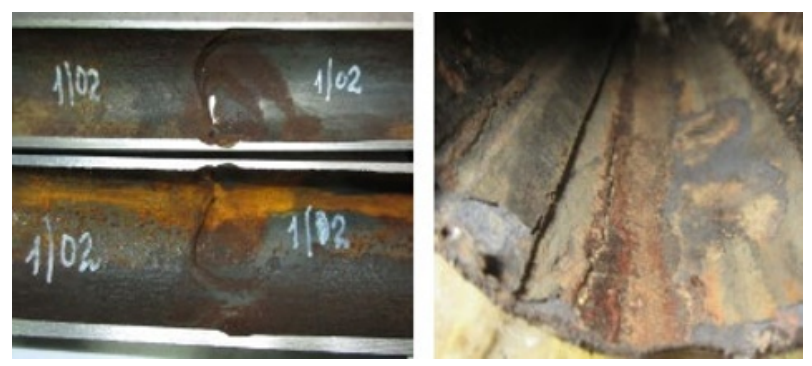

Fig. 9. Corrosion-mechanical wear of the inner surface of tubing in the wells with ESP

An example of corrosion erosion can be damage to the tubing ends during the flow turbulence in the gap between pin ends in the threaded connection (fig. 10).

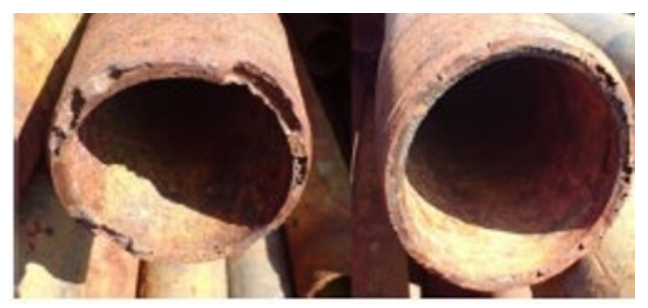

Fig. 10. Corrosive erosion of tubing ends (OAO Tomskneft VNK, 238 days)

Stress corrosion cracking is observed under the impact of tensile stresses and corrosive medium containing $\mathrm{H}_{2} \mathrm{~S}$ (fig. 11). In this case, there are often traces of the wrench tightening found on the couplings in the crack area, which can be stress concentrators, provoking the development of a corrosion crack in the $\mathrm{H}_{2} \mathrm{~S}$ environment. 


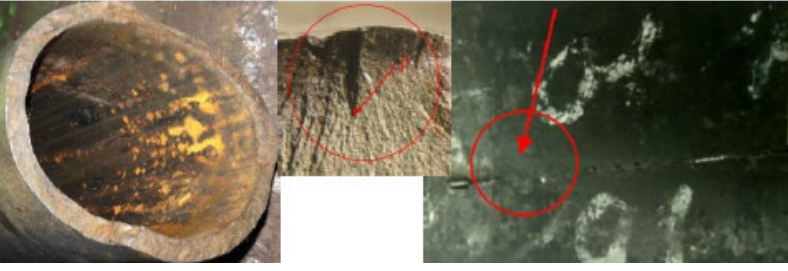

Fig. 11. Sulphide stress cracking of pipes and couplings.

In the course of long-term monitoring of pumping and compressor pipes in various oil companies, defects are identified, the appearance and conditions of formation of which do not allow either to classify them uniquely or to determine the mechanism of destruction.

So, the causes of the localization of corrosion damage on the inner surface of tubing in a form of a longitudinally oriented band of defects, as well as the observed cases of predominant corrosion damage to the tubing string in the range of 200-600 $\mathrm{m}$ from the wellhead, raise questions. Additional analysis is required for the causes of the formation of erosion-corrosion on the inner surface of the tubing in wells with ESP and for the mechanism of formation of Mesa-corrosion with high rate.

\section{The effect of specific factors of operation on the course of corrosion processes}

Analysis of destruction processes under different conditions allowed determining the effect of specific factors of operation on corrosion (table 1).

Table 1. The effect of specific factors of operation on the course of corrosion processes.

\begin{tabular}{|c|c|}
\hline Factor & Impact on the metal \\
\hline $\begin{array}{l}\text { presence of } \\
\mathrm{CO}_{2} \text { and } \mathrm{H}_{2} \mathrm{~S} \\
\left(\mathrm{pCO}_{2} / \mathrm{pH}_{2} \mathrm{~S} \leq\right. \\
20)\end{array}$ & $\begin{array}{l}\text { The predominant course of } \mathrm{H}_{2} \mathrm{~S}- \\
\text { corrosion. As a rule, general uniform } \\
\text { corrosion, the risk of SSC under the } \\
\text { impact of tensile stresses. }\end{array}$ \\
\hline $\begin{array}{l}\text { presence of } \\
\mathrm{CO}_{2} \text { and } \mathrm{H}_{2} \mathrm{~S} \\
\left(20<\mathrm{pCO}_{2} /\right. \\
\left.\mathrm{pH}_{2} \mathrm{~S}<200\right)\end{array}$ & $\begin{array}{l}\text { Mixed corrosion. The most aggressive } \\
\text { corrosion, the presence of significant } \\
\text { amounts of hydrogen sulphide } \\
\text { increases the rate of carbon dioxide } \\
\text { corrosion and leads to additional } \\
\text { localization due to the formation of } \\
\text { porous uneven film of the reaction } \\
\text { products. }\end{array}$ \\
\hline $\begin{array}{l}\text { presence of } \\
\mathrm{CO}_{2} \text { and } \mathrm{H}_{2} \mathrm{~S} \\
\left(\mathrm{pCO}_{2} / \mathrm{pH}_{2} \mathrm{~S} \geq\right. \\
200)\end{array}$ & $\begin{array}{l}\text { The predominant course of } \mathrm{CO}_{2}- \\
\text { corrosion. As a rule, it leads to local } \\
\text { corrosion by ulcers, the probability of } \\
\text { localization increases with increasing } \\
\mathrm{CO}_{2} \text { content and complicating factors } \\
\text { affecting the localization of corrosion } \\
\text { damage (chlorides, mechanical } \\
\text { impurities, erosion processes, etc.) }\end{array}$ \\
\hline salt formation & $\begin{array}{l}\text { Depending on the salt content and } \\
\text { temperature in the well, the formation } \\
\text { of different types of films is possible: } \\
\text { - continuous protective (however: } \\
\text { Local destruction of corrosion }\end{array}$ \\
\hline
\end{tabular}

\begin{tabular}{|c|c|}
\hline Factor & Impact on the metal \\
\hline & $\begin{array}{l}\text { products film provokes mesa } \\
\text { corrosion and corrosion in a form } \\
\text { subsurface ulcers); } \\
\text { - porous non-protective (provokes } \\
\text { localized corrosion), } \\
\text { loose non-protective (uniform } \\
\text { corrosion) }\end{array}$ \\
\hline $\begin{array}{l}\text { presence of } \\
\text { dissolved } \\
\text { oxygen }\end{array}$ & $\begin{array}{l}\text { contributes to a significant increase in } \\
\text { the corrosion rate (general and local) }\end{array}$ \\
\hline $\begin{array}{l}\text { presence of } \\
\text { chloride ions }\end{array}$ & $\begin{array}{l}\text { contributes to accelerate corrosion and } \\
\text { its localization }\end{array}$ \\
\hline $\begin{array}{l}\text { presence of } \\
\text { (suspended } \\
\text { particles) }\end{array}$ & $\begin{array}{l}\text { leads to the localization of corrosion } \\
\text { damage }\end{array}$ \\
\hline $\begin{array}{l}\text { presence of } \\
\text { (sulphate } \\
\text { reducing } \\
\text { bacteria) }\end{array}$ & $\begin{array}{l}\text { leads to acceleration and localization } \\
\text { of corrosion }\end{array}$ \\
\hline $\begin{array}{l}\text { Sucker rod } \\
\text { pump }\end{array}$ & $\begin{array}{l}\text { accelerated corrosion-mechanical } \\
\text { wear of tubing, especially in the } \\
\text { presence of a high amount of } \\
\text { mechanical impurities }\end{array}$ \\
\hline $\begin{array}{l}\text { The pressure at } \\
\text { the pump } \\
\text { intake }\end{array}$ & $\begin{array}{l}\text { acceleration of corrosion processes, } \\
\text { increase of probability of SSC and } \\
\text { HSC }\end{array}$ \\
\hline $\begin{array}{l}\text { Saturation } \\
\text { pressure }\end{array}$ & $\begin{array}{l}\text { when the pressure in the wellbore is } \\
\text { equal to the saturation pressure, the oil } \\
\text { is degassed, while the cavitation } \\
\text { effects of the gas bubbles formed lead } \\
\text { to corrosion-mechanical destruction } \\
\text { of the tubing walls. }\end{array}$ \\
\hline $\begin{array}{l}\text { Temperature } \\
20-40^{\circ} \mathrm{C}\end{array}$ & $\begin{array}{l}\text { Sulphide stress cracking has a } \\
\text { maximum intensity in the temperature } \\
\text { range from } 20 \text { to } 40^{\circ} \mathrm{C} \text {. With an } \\
\text { increase and decrease in temperature } \\
\text { from this range, the intensity of } \\
\text { sulphide stress cracking decreases. }\end{array}$ \\
\hline $\begin{array}{l}\text { Temperature } \\
\text { up to } 100^{\circ} \mathrm{C} \\
\text { and above }\end{array}$ & $\begin{array}{l}\text { As the temperature rises, the rate of } \\
\text { both general and local corrosion } \\
\text { increases. A dense film of corrosion } \\
\text { products is formed. Local destruction } \\
\text { of corrosion products film provokes } \\
\text { mesa corrosion and corrosion in a } \\
\text { form subsurface ulcers }\end{array}$ \\
\hline $\begin{array}{l}\text { Speed of gas- } \\
\text { liquid flows }\end{array}$ & $\begin{array}{l}\text { High speeds of gas-liquid flows in the } \\
\text { tubing string contribute to the local } \\
\text { removal of deposits, which provokes } \\
\text { the development of local corrosion }\end{array}$ \\
\hline $\begin{array}{l}\text { Presence of } \\
\text { asphaltene- } \\
\text { resin-paraffin } \\
\text { deposits }\end{array}$ & $\begin{array}{l}\text { The rate of salt deposition increases, } \\
\text { which is due to the high adsorption } \\
\text { capacity of asphaltene-resin-paraffin } \\
\text { deposits. When removing asphaltene- } \\
\text { resin-paraffin deposits by scraping } \\
\text { corrosion-mechanical wear is } \\
\text { possible. }\end{array}$ \\
\hline
\end{tabular}

\section{Conclusions}


The work carried out allows us to draw the following conclusions.

Despite the fact that the corrosion mechanism is mainly determined by the content of $\mathrm{CO}_{2}, \mathrm{H}_{2} \mathrm{~S}$ and their ratio, it is often the complicating factors that ultimately determine the nature of the destruction, the speed and appearance of the defect.

Understanding of the main regularities of development of corrosion processes depending on the specific operating conditions allows carrying out selection of the best type of tubing for the given conditions more accurately.

Thus, in order to increase the operational reliability of tubing, the selection of the tubing type for specific conditions shall be carried out taking into account the corrosion aggressiveness of the operating conditions, in the evaluation of which both the main and additional corrosion factors acting in the well shall be taken into account.

\section{References}

1. I.V. Scherbakov, N.A. Devyaterikova, Engineering practice, 4, 37 (2019)

2. V.N. Ivanovskiy, Engineering practice, 6, 4 (2010)

3. A.N. Markin, R.E. Nizamov, $\mathrm{CO}_{2}$-corrosion of oilfield equipment (JSC «VNIIOENG», 2003)

4. V.V. Zavyalov, Problems of pipeline operation reliability on late stage of fields development (JSC "VNIIOENG», 2005) 